\title{
COMPETITION IN A RICE - COWPEA INTERCROP AS AFFECTED BY NITROGEN FERTILIZER AND PLANT POPULATION
}

\author{
Frank Oke Oroka ${ }^{1 *}$; Anthony U. Omoregie ${ }^{2}$ \\ ${ }^{1}$ Delta State University - Dept. of Voc. Education (Agric Unit) - 125234 - Abraka, Nigeria. \\ ${ }^{2}$ Ambrose Alli University - Dept. of Crop Science, Ekpoma, Nigeria. \\ *Corresponding author <orkfra@yahoo.com>
}

\begin{abstract}
The increased productivity or yield advantage provided by intercropping is attributed to a better use of resources by crops grown in mixtures, as compared to the same species grown in sole stands. In an intercropping system with upland rice and cowpea, the intra and inter-competition was quantified, as affected by plant population density and rate of nitrogen. Reductions in number of panicles per rice plant and number of grains per panicle were obtained with high density in both sole and mixture rice populations. Increasing nitrogen rate did not affect yield and yield components in both populations, but number and weight of pods per plant of cowpea in sole stands increased. Land equivalent ratios exceeding unity were obtained, indicating an improved resource use by the crop mixture. Relative crowding coefficient and aggressivity indices showed cowpea to be the dominant crop, with rice being dominated. Nitrogen utilization efficiency was high with intercrops, but was generally poor in stands of high population density.

Key words: aggressivity index, land equivalent ratio, nitrogen utilization efficiency, relative crowding coefficient

\section{COMPETIÇÃO EM UMA CULTURACONSORCIADADE ARROZ- GUANDU EM FUNÇÃO DO FERTILIZANTE NITROGENADO E DA DENSIDADE POPULACIONAL DE PLANTAS}

\begin{abstract}
RESUMO: O aumento em produtividade devido a plantios consorciados é atribuído ao melhor uso dos recursos presentes pelas plantas em desenvolvimento conjunto, em comparação às mesmas espécies crescendo em dosséis separados. Em um sistema consorciado de arroz e guandu quantificou-se as inter- e intra competições em relação à densidade populacional e taxa de aplicação de nitrogênio. Reduções significativas do número de panículas por planta de arroz e número de grãos por panícula foram observados para alta densidade, tanto para culturas solteira de arroz como em populações mistas. O aumento das doses de nitrogênio não afetou a produção e os componentes de produção em ambos os sistemas, ao passo que o número e peso de vagens por planta do guandu aumentaram em culturas solteiras. Foram obtidas razões de área equivalente maiores que a unidade, mostrando melhoria no uso da terra nas culturas mistas. O coeficiente relativo de superpopulação e os índices de agressividade mostraram que o guandu é dominante e o arroz dominado. A eficiência do uso de nitrogênio foi alta nas culturas consorciadas, mas em geral baixa para populações de alta densidade.

Palavras-chave: índice de agrssividade, razão de área equivalente, eficiência do fertilizante, coeficiente relativo de superpopulação
\end{abstract}

\section{INTRODUCTION}

Although agricultural research originally focused on sole cropping and ignored the potential of intercropping (Willey \& Osiru, 1972), there has been a gradual recognition of the value of this type of cropping system (Blade, 1992). The essential features of intercropping systems are that they exhibit intensification in space and time, and there is competition be- tween and among the system components for light, water and nutrients.

The yield advantage of intercropping has not been so marked in several situations possibly due to the use of supraoptimal plant population proportions and, in some cases, to the use of suboptimal population proportions for component crops. At higher density $\left(81\right.$ plants $\left.\mathrm{m}^{-2}\right)$ Stylosanthes guianensis reduced the grain yield of upland rice (Shelton \& Humphrey 
1975a). Dahniya et al. (1994) reported decrease in yield and yield components of rice intercropped with a high population of cassava. Fischer et al. (2001) also reported reduction in rice grain and biomass yields in a competition with associated plants. Similar trends have been observed with intercrops of Dolichos lablab with maize and sorghum (Haque, 1984) and high lupin rates and wheat yields (Gardner \& Boundy, 1983).

To maintain intercrop yield, complementarity in patterns of resource use must be taken into account. The goal of this study is to minimize yield losses, but at the same time maintain a level of cropping density that optimizes resource utilization as well as result in high crop yield in the rice - cowpea intercrop.

\section{MATERIAL AND METHODS}

Two field experiments were carried out on a sandy loam Arenic Paleudults ultisol (903 g kg-1 sand; $42 \mathrm{~g} \mathrm{~kg}^{-1}$ silt; $56 \mathrm{~g} \mathrm{~kg}^{-1}$ clay; $\mathrm{pH}$ in water $=4.3$; 3.2 $\mathrm{g} \mathrm{kg}^{-1}$ organic carbon; $0.6 \mathrm{~g} \mathrm{~kg}^{-1}$ total nitrogen) at the experimental farm of the Delta State Agricultural Development Project (ADP), Agbarho, in the tropical rainforest of Southern Nigeria $\left(5^{\circ} 34^{\prime} \mathrm{N}\right.$ and $\left.5^{\circ} 53^{\prime} \mathrm{E}\right)$ in the 2002 and 2003 planting seasons.

Four levels of nitrogen in the form of urea $(0$, 15,30 and $45 \mathrm{~kg} \mathrm{ha}^{-1} \mathrm{~N}$ ), three planting densities $\left(50,000 ; 100,000\right.$ and 200,000 plants ha $\left.{ }^{-1}\right)$ and three cropping patterns (sole rice, sole cowpea and rice cowpea) were arranged in a $4 \times 3 \times 3$ factorial design with randomized complete blocks. The mixture of the rice and cowpea was in a 1:1 ratio (half rice and half cowpea). Varieties of the used crops were ITA 150 (100 - 105 days) and Ife Brown (60 - 80 days) for the rice (Oryza sativa L.) and cowpea (Vigna unguiculata L.Walp), respectively. Data on yield components were collected from 10 randomly selected stands on each plot while data on yield were obtained from net plot areas of $12 \mathrm{~m}^{2}(4.8 \mathrm{~m} \times 2.5 \mathrm{~m})$. Vegetative parts were analyzed for total nitrogen concentration using the micro Kjedahl method (IITA, 1979). Nitrogen use in the interplant competition was evaluated using the nitrogen utilization efficiency-NUE concept (Pal, 1991; Baumann et al., 2001).

$$
\mathrm{NUE}=\frac{\mathrm{Y}_{\mathrm{F}}-\mathrm{Y}_{\mathrm{O}}}{\mathrm{U}_{\mathrm{F}}-\mathrm{U}_{\mathrm{O}}}
$$

where $\mathrm{Y}_{\mathrm{F}}$ and $\mathrm{Y}_{\mathrm{O}}=$ Yield in $\mathrm{kg} \mathrm{ha}^{-1}$ at corresponding fertilizer rates; $U_{F}$ and $U_{O}=$ Uptake of nitrogen in $\mathrm{kg} \mathrm{ha}^{-1}$ at corresponding fertilizer rates.

The intra- and interspecific competition in the rice - cowpea intercropping system was assessed using the land equivalent ratio-LER (Mead \& Willey, 1980), the relative crowding coefficient-K (Willey \& Rao, 1980) and the aggressivity index-A (Mc Gilchrist, 1965):

$$
\operatorname{LER}=\frac{\mathrm{Y}_{\mathrm{ij}}}{\mathrm{Y}_{\mathrm{ii}}}+\frac{\mathrm{Y}_{\mathrm{ji}}}{\mathrm{Y}_{\mathrm{jj}}}
$$

where, $\mathrm{Y}=$ Yield per unit area; $\mathrm{Y}_{\mathrm{ii}}=$ Sole crop yield of crop i (rice); $\mathrm{Y}_{\mathrm{jj}}=$ Sole crop yield of crop j (cowpea); $\mathrm{Y}_{\mathrm{ij}}$ and $\mathrm{Y}_{\mathrm{ji}}=$ yield per unit area of $\mathrm{i}$ intercropped with $\mathrm{j}$ and $\mathrm{j}$ intercropped with $\mathrm{i}$.

When LER is 1 , there is no advantage in intercropping as compared to sole cropping, whereas if LER $>1$, a larger area of land is needed to produce the same yield of both sole crops of each component, in relation to intercropped mixture. A LER $<1.0$ shows a disadvantage of intercropping.

If a species $i$ is in mixture with a species $j$ in a 1:1 mixture of $i$ and $j$, then an individual coefficient, termed the relative crowding coefficient $\mathrm{k}$ can be expressed as

$$
\begin{gathered}
K_{i j}=\frac{Y_{i j}}{Y_{i i}-Y_{j j}} \\
K_{j i}=\frac{Y_{j i}}{Y_{j j}-Y_{j i}}
\end{gathered}
$$

where, $\mathrm{K}_{\mathrm{ij}}$ and $\mathrm{K}_{\mathrm{ji}}=$ relative crowding coefficients of crop $\mathrm{i}$ intercropped with crop $\mathrm{j}$ and crop $\mathrm{j}$ intercropped with $\mathrm{i} ; \mathrm{Y}_{\mathrm{ij}}$ and $\mathrm{Y}_{\mathrm{ji}}=$ yields per unit area of $\mathrm{i}$ intercropped with $\mathrm{j}$ and $\mathrm{j}$ intercropped with $\mathrm{i} ; \mathrm{Y}_{\mathrm{ii}}$ and $\mathrm{Y}_{\mathrm{ij}}=$ yields per unit area of sole crop i and sole crop $\mathrm{j}$.

The crop component that had a higher coefficient was said to be dominant. If the coefficient of a particular crop species is less than, equal to or greater than 1 , then that species has produced less yield, the same yield, or more than "expected", respectively (Willey \& Rao, 1980).

Aggressivity (McGilchrist, 1965) is a measure of how much the relative yield in a species $i$ is greater than that for species $j$. This can be expressed as follows:

$$
A_{i j}=\frac{Y_{i j}}{Y_{i i} \times Z_{i j}}-\frac{Y_{j i}}{Y_{j j} \times Z_{j i}}
$$

$A_{i j}=$ Aggressivity index of crop i intercropped with $\mathrm{j}$; $\mathrm{Y}_{\mathrm{ij}}=$ Yield per unit of crop i intercropped with $\mathrm{j}$; $\mathrm{Y}_{-}-_{\text {ii }}$ and $\mathrm{Y}_{\mathrm{ij}}=$ yield per unit area of sole crop $\mathrm{i}$ and $\mathrm{j} ; \mathrm{Z}_{\mathrm{ji}}=$ Proportion of intercropped area initially allocated to crop i; $\mathrm{Z}_{\mathrm{ji}}=$ Proportion of intercropped area initially allocated to crop j.

If $\mathrm{A}=\mathrm{O}$, the component species are equally competitive, for situations where $A \neq O$, both species will have the same numerical values, only that the value 
of the dominated species will be negative. If the numerical absolute value of $\mathrm{A}$ is large, there is a large difference in the competitive abilities of the two species and the larger is the difference between measured and expected yields.

Values of yield, yield components and total nitrogen of both rice and cowpea were presented as average of two cropping seasons, and were subjected to the appropriate analysis of variance (ANOVA) for factorial and randomized complete block designs (Gomez \& Gomez, 1984) using bivariate techniques for analyzing intercropping trials (Dear \& Mead, 1983; Mutsaers et al., 1997). Comparisons of means of the cropping systems were made by the least significant difference (LSD) $(P<0.05)$.

\section{RESULTS}

Increasing nitrogen rates increased $(P<0.05)$ yield and yield components of rice in sole rice populations (Tables 1, 2, 3), but in the mixtures, only the number of panicles significantly increased (Table 1). However for cowpea, higher nitrogen rates did not increase yield and yield components in sole and mixed populations, respectively.

The number of panicles per rice plant was reduced $(P<0.01)$ by higher densities in mixed populations (Table 1). Number of panicles per plant decreased with planting density in sole and mixture stands of rice, although the sole rice crops had higher number of panicles per plant on average. Increasing planting density from 100,000 to 200,000 plants ha $^{-1}$ decreased panicle number by $26 \%, 38 \%, 47 \%$ and $59 \%$ at 0,15 , 30 and $45 \mathrm{~kg} \mathrm{ha}^{-1}$, respectively, for rice mixtures. This trend did not occur in the sole rice stands. Higher densities decreased $(P<0.05)$ the number of grains per panicle in mixed rice populations (Table 2). Number of pods per plant, weight of pods per plant and grain yield of cowpea in mixed populations presented no increase with increasing plant density (Tables 4, 5, 6). Grain yield of cowpea in sole stands increased $(P<$ 0.05 ) with cropping density (Table 6).

With exception to the number of grains per panicle of rice (Table 1$)$ that decreased $(P<0.05)$ by intercropping with cowpea, other yield and yield components of rice and cowpea had no effect when intercropped (cropping systems).

Interactions $(P<0.01)$ were observed between $\mathrm{N} \times$ density, $\mathrm{N} \times$ cropping system and density $\times$ cropping system in yield and yield components of rice (Tables 1, 2, 3). Weight of pods per plant showed no significant interactions with cowpea. Cowpea grain yield indicated $(P<0.05)$ density $\mathrm{x}$ system interactions. However, the number of pods presented significant interactions with $\mathrm{N} \times$ density $(P<0.05), \mathrm{N} \times$ cropping system and density $\mathrm{x}$ cropping system $(P<0.01)$ (Tables 4, 5, 6).

A yield advantage of intercropping was observed at all levels of nitrogen and plant densities for the rice-cowpea mixture. This is shown by the (LER) values in Table 7 . The low $\left(50,000\right.$ plants $\left.\mathrm{ha}^{-1}\right)$ and medium $\left(100,000\right.$ plants $\left.\mathrm{ha}^{-1}\right)$ plant population densities recorded yield advantages ranging from LER 1.92 to 2.30 and LER 1.79 to 2.14, respectively. A lower LER range of 1.47 to 1.68 was observed for the high plant density (200,000 plants ha $\left.{ }^{-1}\right)$. Yield advantage due to nitrogen was more pronounced at $15 \mathrm{~kg} \mathrm{ha}^{-1} \mathrm{~N}$ (LER 2.22) and $30 \mathrm{~kg} \mathrm{ha}^{-1} \mathrm{~N}$ (LER 2.30) at the lowest

Table 1 - Number of panicles of rice planted sole and intercropped with cowpea at varying nitrogen levels and cropping densities.

\begin{tabular}{|c|c|c|c|c|c|c|c|c|c|}
\hline \multicolumn{10}{|c|}{ Cropping density (plants ha-1) } \\
\hline \multicolumn{5}{|c|}{ Sole rice } & \multicolumn{5}{|c|}{ Mixed rice } \\
\hline $\begin{array}{l}\text { Rate of Nitrogen } \\
\left(\mathrm{kg} \mathrm{ha}^{-1} \mathrm{~N}\right)\end{array}$ & 50,000 & 100,000 & 200,000 & Mean & $\begin{array}{c}\text { Rate of Nitrogen } \\
\left(\mathrm{kg} \mathrm{ha}^{-1} \mathrm{~N}\right)\end{array}$ & 50,000 & 100,000 & 200,000 & Mean \\
\hline 0 & 2.07 & 2.10 & 1.93 & $2.03 \mathrm{~b}$ & 0 & 2.20 & 2.17 & 1.60 & $1.99 \mathrm{~b}$ \\
\hline 15 & 2.33 & 2.30 & 2.07 & $2.23 \mathrm{~b}$ & 15 & 2.17 & 3.00 & 1.87 & $2.35 \mathrm{ab}$ \\
\hline 30 & 3.97 & 4.10 & 3.87 & 3.98 a & 30 & 3.90 & 3.60 & 1.90 & 3.13 a \\
\hline 45 & 4.00 & 4.10 & 4.10 & $4.07 \mathrm{a}$ & 45 & 4.10 & 4.00 & 1.63 & $3.24 \mathrm{a}$ \\
\hline Mean & 3.09 a & 3.15 a & 2.99 a & & Mean & 3.09 a & 3.19 a & 1.75 a & \\
\hline \multicolumn{10}{|l|}{ Interactions } \\
\hline $\mathrm{N} \times \mathrm{D}$ & $10.40 * *$ & & & & & & & & \\
\hline $\mathrm{N} \times \mathrm{S}$ & $27.93 * *$ & & & & & & & & \\
\hline $\mathrm{D} \times \mathrm{S}$ & $75.53 * *$ & & & & & & & & \\
\hline
\end{tabular}

In each column or row, means followed by the same letter(s) do not differ at 5\% LSD. **Significant at $1 \%$. N- nitrogen dose; D-cropping density; S - cropping system. 
Table 2 - Number of grains per panicle of rice planted sole and intercropped with cowpea at varying nitrogen levels and cropping densities.

\begin{tabular}{|c|c|c|c|c|c|c|c|c|c|}
\hline \multicolumn{10}{|c|}{ Cropping density (plants ha-1) } \\
\hline \multicolumn{5}{|c|}{ Sole rice } & \multicolumn{5}{|c|}{ Mixed rice } \\
\hline $\begin{array}{l}\text { Rate of Nitrogen } \\
\left(\mathrm{kg} \mathrm{ha}^{-1} \mathrm{~N}\right)\end{array}$ & 50,000 & 100,000 & 200,000 & Mean & $\begin{array}{l}\text { Rate of Nitrogen } \\
\qquad\left(\mathrm{kg} \mathrm{ha}^{-1} \mathrm{~N}\right)\end{array}$ & 50,000 & 50,000 & 50,000 & Mean \\
\hline 0 & 64.33 & 64.73 & 60.37 & $63.14 \mathrm{~b}$ & 0 & 64.73 & 63.47 & 60.37 & 62.86 \\
\hline 15 & 75.70 & 70.00 & 64.73 & $70.14 \mathrm{~b}$ & 15 & 64.33 & 63.70 & 50.83 & 59.62 \\
\hline 30 & 97.20 & 96.88 & 88.70 & 94.26 a & 30 & 66.30 & 68.70 & 50.87 & 61.96 \\
\hline 45 & 100.33 & 99.70 & 96.60 & 98.88 a & 45 & 69.73 & 66.63 & 51.07 & 62.48 \\
\hline Mean & 84.39 a & 82.83 a & 77.60 a & & Mean & $66.27 \mathrm{a}$ & 65.63 a & $53.29 \mathrm{~b}$ & \\
\hline \multicolumn{10}{|l|}{ Interactions } \\
\hline $\mathrm{N} \times \mathrm{D}$ & $53.12 * *$ & & & & & & & & \\
\hline $\mathrm{N} \times \mathrm{S}$ & $52.38 * *$ & & & & & & & & \\
\hline $\mathrm{D} \times \mathrm{S}$ & $121.47 * *$ & & & & & & & & \\
\hline
\end{tabular}

In each column or row, means followed by the same letter(s) do not differ at 5\% LSD. **Significant at 1\%; N - nitrogen dose; D cropping density; S - cropping system.

Table 3 - Grain yield $\left(\mathrm{kg} \mathrm{ha}^{-1}\right)$ of rice planted sole and intercropped with cowpea at varying nitrogen levels and cropping densities.

\begin{tabular}{|c|c|c|c|c|c|c|c|c|c|}
\hline \multicolumn{10}{|c|}{ Cropping density (plants ha-1) } \\
\hline \multicolumn{5}{|c|}{ Sole rice } & \multicolumn{5}{|c|}{ Mixed rice } \\
\hline $\begin{array}{l}\text { Rate of Nitrogen } \\
\left(\mathrm{kg} \mathrm{ha}^{-1} \mathrm{~N}\right)\end{array}$ & 50,000 & 100,000 & 200,000 & Mean & $\begin{array}{c}\text { Rate of Nitrogen } \\
\left(\mathrm{kg} \mathrm{ha}^{-1} \mathrm{~N}\right)\end{array}$ & 50,000 & 100,000 & 200,000 & Mean \\
\hline 0 & 880.14 & 1260.53 & 1451.41 & $1197.30 \mathrm{~b}$ & 0 & 903.14 & 1016.21 & 1202.15 & $1040.50 \mathrm{a}$ \\
\hline 15 & 980.35 & 1308.11 & 1513.18 & $1267.21 \mathrm{~b}$ & 15 & 1153.50 & 1369.17 & 1163.14 & $1228.60 \mathrm{a}$ \\
\hline 30 & 1001.23 & 1400.11 & 1898.24 & $1433.19 \mathrm{ab}$ & 30 & 1258.32 & 1300.16 & 1181.13 & 1246.54 a \\
\hline 45 & 1147.32 & 1441.23 & 2090.17 & 1559.57 a & 45 & 1278.17 & 1290.15 & 1170.20 & $1246.17 \mathrm{a}$ \\
\hline Mean & 1002.32 c & $1352.50 \mathrm{~b}$ & 1738.25 & & Mean & 1148.28 & a 1243.92 a & a 1179.16 a & \\
\hline \multicolumn{10}{|l|}{ Interactions } \\
\hline $\mathrm{N} \times \mathrm{D}$ & $21.88 * *$ & & & & & & & & \\
\hline $\mathrm{N} \times \mathrm{S}$ & $61.61^{* *}$ & & & & & & & & \\
\hline $\mathrm{D} \times \mathrm{S}$ & $70.25 * *$ & & & & & & & & \\
\hline
\end{tabular}

In each column or row, means followed by the same letter(s) do not differ at 5\% LSD. **Significant at $1 \%$; $\mathrm{N}$ - nitrogen dose; D cropping density; $\mathrm{S}$ - cropping system.

planting density. High nitrogen levels of $30 \mathrm{~kg} \mathrm{ha}^{-1} \mathrm{~N}$ and $45 \mathrm{~kg} \mathrm{ha}^{-1} \mathrm{~N}$ with high plant population density $\left(200,000\right.$ plants $\left.\mathrm{ha}^{-1}\right)$ gave lower intercrop yield advantage of LER 1.53 and 1.47, respectively.

Values of the aggressivity indices (A) indicated that cowpea is the dominant crop (Table 7). The values of $\mathrm{A}$ are high at $30 \mathrm{~kg} \mathrm{ha}^{-1} \mathrm{~N}$ and high plant population densities. At all levels of nitrogen with low plant population density (50,000 plants ha $\left.{ }^{-1}\right)$, rice was more aggressive, hence the dominant crop.

The relative crowding coefficient values also indicate that cowpea was dominant in the rice-cowpea intercropping system in this study (Table 7). The dominant attribute of the cowpea was expressed more at high plant population densities. However, rice was more dominant at all levels of nitrogen with low plant population density (50,000 plants ha $\left.{ }^{-1}\right)$. Both rice and cowpea yields in the intercrop at all nitrogen levels were less than expected in plots with low plant population density.

Compared to their sole crop stands, NUE was generally higher in all mixed stands of rice and cowpea (Table 8). In rice, NUE was higher with sole crops in medium $\left(100,000\right.$ plants $\left.\mathrm{ha}^{-1}\right)$ and high $(200,000$ plants $h^{-1}$ ) plant population densities. Negative NUE values were obtained for most of the sole cowpea plots, except at $30 \mathrm{~kg} \mathrm{ha}^{-1} \mathrm{~N}$ with planting density of 100,000 plants $\mathrm{ha}^{-1}$. At the low nitrogen rate of 15 $\mathrm{kg} \mathrm{ha}^{-1} \mathrm{~N}$, high values of NUE were obtained for both mixed and sole rice crop stands at medium and high planting densities. 
Table 4 - Number of pods per plant of cowpea planted sole and intercropped with rice at varying nitrogen levels and cropping densities.

\begin{tabular}{|c|c|c|c|c|c|c|c|c|c|}
\hline \multicolumn{10}{|c|}{ Cropping density (plants ha ${ }^{-1}$ ) } \\
\hline \multicolumn{5}{|c|}{ Sole cowpea } & \multicolumn{5}{|c|}{ Mixed cowpea } \\
\hline $\begin{array}{l}\text { Rate of Nitrogen } \\
\left(\mathrm{kg} \mathrm{ha}^{-1} \mathrm{~N}\right)\end{array}$ & 50,000 & 100,000 & 200,000 & Mean & $\begin{array}{l}\text { Rate of Nitrogen } \\
\qquad\left(\mathrm{kg} \mathrm{ha}^{-1} \mathrm{~N}\right)\end{array}$ & 50,000 & 100,000 & 200,000 & Mean \\
\hline 0 & 16.30 & 17.50 & 16.13 & 16.64 a & 0 & 16.83 & 18.53 & 13.67 & 16.34 a \\
\hline 15 & 18.27 & 17.30 & 14.87 & $16.81 \mathrm{a}$ & 15 & 17.25 & 18.40 & 14.33 & $16.66 \mathrm{a}$ \\
\hline 30 & 19.27 & 20.37 & 17.37 & 19.00 a & 30 & 16.33 & 17.60 & 15.07 & 16.33 a \\
\hline 45 & 21.53 & 19.70 & 15.97 & 19.07 a & 45 & 20.03 & 19.83 & 18.63 & $19.50 \mathrm{a}$ \\
\hline Mean & $18.84 \mathrm{a}$ & $18.71 \mathrm{a}$ & $16.09 \mathrm{a}$ & & Mean & $17.61 \mathrm{a}$ & 18.59 a & $15.43 \mathrm{a}$ & \\
\hline
\end{tabular}

Interactions

$\begin{array}{lc}\mathrm{N} \times \mathrm{D} & 3.68 * \\ \mathrm{~N} \times \mathrm{S} & 18.02 * * \\ \mathrm{D} \times \mathrm{S} & 22.46 * *\end{array}$

In each column or row, means followed by the same letter(s) do not differ at 5\% LSD. *Significant at 5\%; **Significant at $1 \%$; $\mathrm{N}$ nitrogen dose; D-cropping density; S- cropping system.

Table 5 - Weight of pods (g/plant) of cowpea planted sole and intercropped with rice at varying nitrogen levels and cropping densities.

\begin{tabular}{|c|c|c|c|c|c|c|c|c|c|}
\hline \multicolumn{10}{|c|}{ Cropping density (plants ha-1) } \\
\hline \multicolumn{5}{|c|}{ Sole cowpea } & \multicolumn{5}{|c|}{ Mixed cowpea } \\
\hline $\begin{array}{l}\text { Rate of Nitrogen } \\
\left(\mathrm{kg} \mathrm{ha}^{-1} \mathrm{~N}\right)\end{array}$ & 50,000 & 100,000 & 200,000 & Mean & $\begin{array}{l}\text { Rate of Nitrogen } \\
\qquad\left(\mathrm{kg} \mathrm{ha}{ }^{-1} \mathrm{~N}\right)\end{array}$ & 50,000 & 100,000 & 200,000 & Mean \\
\hline 0 & 22.38 & 20.05 & 21.95 & 21.46 a & 0 & 22.52 & 22.32 & 20.65 & 21.83 \\
\hline 15 & 21.28 & 25.62 & 24.15 & 23.68 a & 15 & 23.58 & 22.51 & 23.01 & $23.03 \mathrm{a}$ \\
\hline 30 & 23.95 & 25.13 & 24.06 & 24.38 a & 30 & 20.15 & 23.11 & 22.92 & $22.06 \mathrm{a}$ \\
\hline 45 & 24.91 & 24.02 & 23.88 & $24.27 \mathrm{a}$ & 45 & 24.62 & 23.85 & 22.42 & $23.63 a$ \\
\hline Mean & 23.13 a & 23.71 a & 23.51 a & & Mean & 22.72 a & 22.95 a & 22.25 a & \\
\hline \multicolumn{10}{|l|}{ Interactions } \\
\hline $\mathrm{N} \times \mathrm{D}$ & $1.54 \mathrm{~ns}$ & & & & & & & & \\
\hline $\mathrm{N} \times \mathrm{S}$ & $2.67 \mathrm{~ns}$ & & & & & & & & \\
\hline $\mathrm{D} \times \mathrm{S}$ & $6.53^{*}$ & & & & & & & & \\
\hline
\end{tabular}

In each column or row, means followed by the same letter(s) do not differ at 5\% LSD. *Significant at 5\%; ns - not significant; $\mathrm{N}$ - nitrogen dose; D - cropping density; S - cropping system.

\section{DISCUSSION}

The decline in yield components of rice in intercrops with high plant population densities, despite high nitrogen rates, may be attributed to excessive plant population resulting in intra- and inter-competition for light, water and nutrients, consequently resulting in low availability of these factors for vegetative and reproductive development. (Alofe \& Ayotade, 1997). However, the increase in grain yield of sole rice and cowpea with increasing plant density was as result of the increase in yield components per unit area. This is further supported by Sipaseuth et al. (2001) who reported increased yields by $13 \%$ to $31 \%$ when the stand density increased from 16 stands $\mathrm{m}^{-2}(25 \times 25 \mathrm{~cm})$ to 25 and 44 stands $\mathrm{m}^{-2}$, respectively as a result of increased panicle density.

Non-signifance of nitrogen on most yield and yield components of rice and cowpea may be due to the high precipitation that occurred during the period of study, which may be associated to nitrogen mineralization and subsequent leaching losses. Poor growth of cereals and cowpea in southern Nigeria is due to the leached acid soils (ferallitic soils $\mathrm{pH}$ 4.5) found in high rainfall areas of the south, and drained acid soils (pH 3.5) of the delta areas and marshy coasts (Enwezor et al., 1989).

Results obtained for the intercropping ratios, gave land equivalent ratios exceeding unity, indicating an intercrop advantage and hence an apparent increase 
Table 6 - Seed yield $\left(\mathrm{kg} \mathrm{ha}^{-1}\right)$ of cowpea planted sole and intercropped with rice at varying nitrogen levels and cropping densities.

\begin{tabular}{|c|c|c|c|c|c|c|c|c|c|}
\hline \multicolumn{10}{|c|}{ Cropping density (plants ha ${ }^{-1}$ ) } \\
\hline \multicolumn{5}{|c|}{ Sole cowpe } & \multicolumn{5}{|c|}{ Mixed cowpea } \\
\hline $\begin{array}{l}\text { Rate of Nitrogen } \\
\left(\mathrm{kg} \mathrm{ha}^{-1} \mathrm{~N}\right)\end{array}$ & 50,000 & 100,000 & 200,000 & Mean & $\begin{array}{c}\text { Rate of Nitrogen } \\
\left(\mathrm{kg} \mathrm{ha}^{-1} \mathrm{~N}\right)\end{array}$ & 50,000 & 100,000 & 200,000 & Mean \\
\hline 0 & 800.40 & 918.20 & 1106.18 & 941.59 a & 0 & 807.11 & 900.24 & 936.22 & $881.19 \mathrm{a}$ \\
\hline 15 & 818.24 & 904.83 & 1116.17 & $946.41 \mathrm{a}$ & 15 & 848.11 & 989.72 & 1002.62 & 946.82 a \\
\hline 30 & 823.42 & 898.36 & 1109.20 & 943.66 a & 30 & 860.36 & 900.42 & 1007.82 & $922.87 \mathrm{a}$ \\
\hline 45 & 840.36 & 900.76 & 1150.32 & 963.81 a & 45 & 868.22 & 943.14 & 1047.29 & 952.88 a \\
\hline Mean & 820.61 b & $905.54 \mathrm{~b}$ & 1120.47 a & & Mean & 848.95 a & 933.38 a & 998.49 a & \\
\hline \multicolumn{10}{|l|}{ Interactions } \\
\hline $\mathrm{N} \times \mathrm{D}$ & $2.21 \mathrm{~ns}$ & & & & & & & & \\
\hline $\mathrm{N} \times \mathrm{S}$ & $2.63 n s$ & & & & & & & & \\
\hline $\mathrm{D} \times \mathrm{S}$ & $7.29 *$ & & & & & & & & \\
\hline
\end{tabular}

In each column or row, means followed by the same letter(s) do not differ at 5\% LSD. *Significant at 5\%; ns - not significant; $\mathrm{N}$ - nitrogen dose; D - cropping density; S - cropping system.

Table 7 - Land equivalent ratio (LER), relative crowding coefficient (k) and aggressivity index (A) for mixtures of rice and cowpea at different densities and nitrogen levels.

\begin{tabular}{|c|c|c|c|c|c|c|}
\hline \multirow{2}{*}{$\mathrm{N}$ level } & \multirow{2}{*}{ Density } & \multirow[t]{2}{*}{ LER } & \multicolumn{2}{|c|}{$\mathrm{k}$} & \multicolumn{2}{|c|}{ A } \\
\hline & & & Rice & Cowpea & Rice & Cowpea \\
\hline \multicolumn{7}{|c|}{$0 \mathrm{~kg} \mathrm{ha}^{-1} \mathrm{~N}$} \\
\hline & 50,000 plants ha- ${ }^{-1}$ & 2.04 & -39.26 & -120.28 & 0.03 & -0.03 \\
\hline & 100,000 plants ha ${ }^{-1}$ & 1.79 & 4.16 & 50.12 & -0.43 & 0.43 \\
\hline & 200,000 plants ha $^{-1}$ & 1.68 & 4.82 & 5.51 & -0.03 & 0.03 \\
\hline \multicolumn{7}{|c|}{$15 \mathrm{~kg} \mathrm{ha}^{-1} \mathrm{~N}$} \\
\hline & 50,000 plants ha $^{-1}$ & 2.22 & -6.66 & -42.68 & 0.30 & -0.03 \\
\hline & 100,000 plants ha ${ }^{-1}$ & 2.14 & -22.42 & -11.66 & -0.10 & 0.10 \\
\hline & 200,000 plants ha $^{-1}$ & 1.67 & 3.32 & 8.83 & -0.26 & 0.26 \\
\hline \multicolumn{7}{|c|}{$30 \mathrm{~kg} \mathrm{ha}^{-1} \mathrm{~N}$} \\
\hline & 50,000 plants ha ${ }^{-1}$ & 2.30 & -4.89 & -23.29 & 0.42 & -0.42 \\
\hline & 100,000 plants ha ${ }^{-1}$ & 1.92 & 13.01 & -437.10 & -0.14 & 0.14 \\
\hline & 200,000 plants ha ${ }^{-1}$ & 1.53 & 1.65 & 9.94 & -0.58 & 0.58 \\
\hline \multicolumn{7}{|c|}{$45 \mathrm{~kg} \mathrm{ha}^{-1} \mathrm{~N}$} \\
\hline & 50,000 plants ha $^{-1}$ & 2.14 & -31.16 & -9.77 & 0.16 & -0.16 \\
\hline & 100,000 plants ha ${ }^{-1}$ & 1.95 & 8.54 & -27.68 & -0.30 & 0.30 \\
\hline & 200,000 plants ha $^{-1}$ & 1.47 & 1.27 & 10.16 & -0.70 & 0.70 \\
\hline
\end{tabular}

in resource use efficiency by the crop mixture (Table 7). The yield advantage of the rice-cowpea mixture may be attributable to more efficient light utilization in combination to tall rice and short cowpea. Differences in growth cycles between the crops, enabling more efficient use of available water and nutrients can also be important (Willey \& Osiru, 1972; Webster \& Wilson, 1980). Therefore, the crop mixture improved the resource use through higher yield, which may be attributed to a density effect. However, lower LER was observed at high plant population density. Similar re- search reports in a rice-cassava intercrop in Sierra Leone were reported by Dahniya et al. (1994), who noted highest LER with low density (1.85 and 1.73) and high intercrop density giving lower LER (1.54 and 1.13).

Competition effects were not observed at low densities (50,000 plants $\left.\mathrm{ha}^{-1}\right)$ because densities were lower than optimum density, hence $\mathrm{K}$ values were below unity. This may have resulted in inadequate utilization of resources (Baumann et al., 2001). From values of the crowding coefficient and aggressivity indi- 
Table 8 - Nitrogen utilization efficiency (NUE) of rice and cowpea grown at different cropping densities and nitrogen levels.

\begin{tabular}{|c|c|c|c|c|c|}
\hline \multirow{2}{*}{$\mathrm{N}$ level } & \multirow{2}{*}{ Density } & \multicolumn{2}{|c|}{ Rice } & \multicolumn{2}{|c|}{ Cowpea } \\
\hline & & Sole & Mixed & Sole & Mixed \\
\hline \multicolumn{6}{|c|}{$15 \mathrm{~kg} \mathrm{ha}^{-1} \mathrm{~N}$} \\
\hline & 50,000 plants ha $^{-1}$ & -52.45 & 243.07 & 0.59 & 0.66 \\
\hline & 100,000 plants ha ${ }^{-1}$ & 13.71 & -371.04 & -0.82 & 1.07 \\
\hline & 200,000 plants ha $^{-1}$ & 5.27 & 25.33 & -0.10 & 0.56 \\
\hline \multicolumn{6}{|c|}{$30 \mathrm{~kg} \mathrm{ha}^{-1} \mathrm{~N}$} \\
\hline & 50,000 plants $\mathrm{ha}^{-1}$ & -11.16 & 10.00 & -0.57 & 7.63 \\
\hline & 100,000 plants ha $^{-1}$ & -6.01 & 5.03 & 0.34 & 0.02 \\
\hline & 200,000 plants ha ${ }^{-1}$ & -54.76 & -0.81 & -0.05 & 8.98 \\
\hline \multicolumn{6}{|c|}{$45 \mathrm{~kg} \mathrm{ha}^{-1} \mathrm{~N}$} \\
\hline & 50,000 plants ha ${ }^{-1}$ & -38.72 & 54.99 & -0.94 & 7.40 \\
\hline & 100,000 plants ha $^{-1}$ & -10.31 & 19.21 & -1.03 & 0.14 \\
\hline & 200,000 plants ha $^{-1}$ & -55.35 & 20.75 & -0.48 & 0.32 \\
\hline
\end{tabular}

Table 9 - Nitrogen uptake ( $\left.\mathrm{kg} \mathrm{ha}^{-1}\right)$ of rice and cowpea grown at different cropping densities and nitrogen levels.

\begin{tabular}{|c|c|c|c|c|c|}
\hline \multirow{2}{*}{$\mathrm{N}$ level } & \multirow{2}{*}{ Density } & \multicolumn{2}{|c|}{ Rice } & \multicolumn{2}{|c|}{ Cowpea } \\
\hline & & Sole & Mixed & Sole & Mixed \\
\hline \multicolumn{6}{|c|}{$0 \mathrm{~kg} \mathrm{ha}^{-1} \mathrm{~N}$} \\
\hline & 50,000 plants ha ${ }^{-1}$ & 16.75 & 9.54 & 99.51 & 32.14 \\
\hline & 100,000 plants ha $^{-1}$ & 31.94 & 14.08 & 75.83 & 71.40 \\
\hline & 200,000 plants ha ${ }^{-1}$ & 14.24 & 47.40 & 149.68 & 26.80 \\
\hline \multicolumn{6}{|c|}{$15 \mathrm{~kg} \mathrm{ha}^{-1} \mathrm{~N}$} \\
\hline & 50,000 plants ha $^{-1}$ & 14.84 & 10.57 & 69.49 & 94.05 \\
\hline & 100,000 plants ha- ${ }^{-1}$ & 35.41 & 13.13 & 92.20 & 154.99 \\
\hline & 200,000 plants ha $^{-1}$ & 25.96 & 45.86 & 47.20 & 145.04 \\
\hline \multicolumn{6}{|c|}{$30 \mathrm{~kg} \mathrm{ha}^{-1} \mathrm{~N}$} \\
\hline & 50,000 plants ha- ${ }^{-1}$ & 5.90 & 45.05 & 59.32 & 39.12 \\
\hline & 100,000 plants ha $^{-1}$ & 8.68 & 70.52 & 41.98 & 83.30 \\
\hline & 200,000 plants ha ${ }^{-1}$ & 6.08 & 73.38 & 84.80 & 213.68 \\
\hline \multicolumn{6}{|c|}{$45 \mathrm{~kg} \mathrm{ha}^{-1} \mathrm{~N}$} \\
\hline & 50,000 plants ha $^{-1}$ & 9.85 & 16.36 & 57.12 & 40.40 \\
\hline & 100,000 plants ha $^{-1}$ & 14.42 & 28.34 & 92.69 & 78.69 \\
\hline & 200,000 plants ha $^{-1}$ & 2.70 & 21.72 & 57.66 & 377.80 \\
\hline
\end{tabular}

ces, cowpea appears to be the dominant crop, and rice the dominated crop. The dominance of cowpea in the intercrop may be due to its phenological attributes; trailing or branching (Abayomi et al., 2001) during the period of growth. This is supported by Sullivan (2001), who noted that in a cereal - legume intercrop, an aggressive climbing bean might pull down rice, maize or sorghum growing with it and lower the grain yield. The impact may be more severe for smaller cereals like rice.

The dominant nature of the cowpea may also be a result of its better ability to capture light and soil resources or a combination of the two. Cowpea, with its more trifoliate leaves, has better ability to capture light than rice does, with its narrow upright leaves. These views are supported by related studies (Brewster, 1994; Baumann et al., 2001).

Nitrogen use often is greater for intercropping (Dalal, 1974; Liboon \& Harwood, 1975), and high nitrogen use efficiency for both rice and cowpea mixtures confirm these findings (Table 8). The high interspecific competition at high densities of rice and cowpea mixed stands resulted in very low NUE. The results from the rice- cowpea intercropping system in this study indicate that higher nitrogen rates cannot 
compensate for interspecific competition. Improving advantages due to intercrop is a matter of maximizing the degree of complementarity between the component crops and minimizing intercrop competition (Willey, 1979a). Intercrop performance of the rice-cowpea mixture can be improved with respect to temporal and spatial complementarity and also by improving the compatibility of genotypes used as components of the mixture (Willey, 1979b). An example to account for temporal differences in resource use by the crops may involve staggering the relative planting time of the crops. Increased yield advantages due to staggering of the component crops have been shown in other studies (IRRI, 1973; Osiru \& Willey, 1976; Mohamed Saleem, 1984).

The space allocated to the component crops is directly related to the resources available for both crops. However, De Wit et al. (1979) found in their row spacing experiments that within a certain range of plant densities, yield is not affected. For rice and cowpea, the present study showed that there is a response of rice yield to intercrop density. Hence, for cereal-legume intercrops, it is important that the population of the cereal crop be as close as possible to its maximum monocrop population, and the density of the legume should not be so high as to substantially decrease grain yield. Another possibility is the selection of suitable genotypes for the crop mixture. As emphasized by Willey (1979b), it seems likely that this offers just as much scope for crop performance improvement as it does in sole cropping. The selection minimizes intercrop competition and maximizes complementary effects. This is supported by an experiment with rice in northeast Thailand, in which undersowing a medium-duration variety with Stylosanthes guianensis gave little or no difference whether the rice was undersown simultaneously or 10 days later (Shelton \& Humphreys, 1975b).

This study supports the idea that the highest fertilizer rate applied does not imply in maximized yield. Since there was no improved rice yield between 30 and $45 \mathrm{~kg} \mathrm{ha}^{-1} \mathrm{~N}, 30 \mathrm{~kg} \mathrm{ha}^{-1} \mathrm{~N}$ will be more economical and acceptable to the rice farmers in the area of study for intercrops of rice, but for sole rice farmers, the rate of $45 \mathrm{~kg} \mathrm{ha}^{-1} \mathrm{~N}$ is recommended. However, for sole and mixture populations of cowpea, $45 \mathrm{~kg} \mathrm{ha}^{-1} \mathrm{~N}$ is recommended to maximize yields.

Highest yield was obtained for high plant densities. The ease with which the peasant farmer in this area can complete the planting of his large acres of land within a minimum period at reduced cost is a major problem to combat with. Cropping densities of 200,000 plants $\mathrm{ha}^{-1}$ may be sufficient for maximum grain yields in sole cowpea, sole rice and rice-cowpea.

\section{ACKNOWLEDGEMENT}

To the staff of Delta State Agricultural Development Project, for their technical assistance during the course of the experiment.

\section{REFERENCES}

ABAYOMI, Y.A.; FADAYOMI, O.; BABATOLA, J.O.; TIAN, G. Evaluation of selected legume cover crops for biomass production, dry season survival and soil fertility improvement in a moist savanna location in Nigeria. African Crop Science Journal, v.9, p.615-627, 2001.

ALOFE, C.O.; OYETADE, T.I. Effects of number of plants per hill and within row spacing on grain yield performance of open - pollinated and hybrid maize Ife Journal of Agriculture, v.19, p.44-53, 1997.

BAUMANN, D.T.; BASTIAANS, L.; OPFF, M.J.K. Competition and crop performance in a leek - celery intercropping system. Crop Science, v.41, p.764-774, 2001.

BLADE, S.F. Evaluation of Cowpea lines in Nigerian Cropping Systems. Montreal: McGill University, 1992. (Thesis Ph.D.).

BREWSTER, J.L. Onions and other vegetable alliums. Oxon: CAB International, 1994.

DAHNIYA, M.T.; JALLOH, A.; EZUMAH, H.C. Intercrop yields of cassava and rice as influenced by cassava variety and population. In: OFORI, F.; HAHN, S.K. (Ed.). Root crops in a developing economy. Ibadan: International Institute for Tropical Agriculture, 1994. p.194-199.

DALAL, R.C. Effects of intercropping maize with pigeon peas on grain yield and nutrient uptake. Experimental Agriculture, v.10, p.219-224, 1974.

DEAR, K.B.G.; MEAD, R. The use of bivariate analysis techniques for the presenting analysis and interpretation of data. Statistics in intercropping. Reading: University of Reading, Department of Applied Statistics, 1983. (Technical Report, 1).

DE WIT, C.T.; VAN LAAR, H.H.; VAN KELVEN, H. Physiological potential of crop production. In: SNEEP, J.; HENDRIKSEN, A.J.K. (Ed.). Plant breeding perspectives. Wageningen: Indoc, 1979. p.47-82.

ENWEZOR, W.O.; UDO, E.J.; USOROH, N.J.; AYOTADE, K.A.; ADEPETU, J.A. (Ed.). Fertilizer use and management practices for crops in Nigeria. Lagos: Federal Ministry of Agriculture and Rural Development, 1989. p.20-45. (Series, 2).

FISCHER, A.J.; RAMIREZ, H.V.; GIBSON, K.D.; PINHEIRO, B.D. Competitiveness of Semidwarf upland rice cultivars against Signal grass (Brachiaria decumbens). Agronomy Journal, v.93, p.967-973, 2001.

GARDNER, W.K.; BOUNDY, K.A. The acquisition of phosphorus by Lupinus albus L. IV. The effect of interplanting wheat and white Iupine on the growth and mineral composition of the two species. Plant and Soil, v.70, p.391-402, 1983.

GOMEZ, K.A.; GOMEZ, A.A. Statistical procedures for agricultural research. New York: John Wiley \& Sons, 1984.

HAQUE, I. Effect of intercropping lablab on dry matter, grain yield and crude protein of maize and sorghum. Addis Ababa, Ethiopia: ILCA, 1984.

INTERNATIONAL INSTITUTE OF TROPICAL AGRICULTURE - IITA. Automated and semi-automated methods for soil and plant analysis. Ibadan, Nigeria: IITA, 1979. (Manual Series, 7).

INTERNATIONAL RICE RESEARCH INSTITUTE - IRRI. Annual report of IRRI. Los Banos, 1973. p.15-34: Multiple cropping. 
LIBOON, S.P.; HARWOOD, R.R. Nitrogen response in corn/ soybean intercropping. In: ANNUAL SCIENCE MEETING OF PHILIPPINES CROP SCIENCE SOCIETY, 6., Bacolod City, 1975. Proceedings. Bacolod: Philippines Crop Science Society, 1975.

McGILCHRIST, C.A. Analysis of competition experiments. Biometrics, v.21, p.975-995, 1965.

MEAD, R.; WILLEY, R.W. The concept of "Land Equivalent Ratio" and advantage in yields from intercropping. Experimental Agriculture, v.16, p.217-228, 1980.

MOHAMMED-SALEEM, M.A. Crop forage interaction. In: ILCA/ NAPRI SYMPOSIUM ON LIVESTOCK PRODUCTION IN THE SUBHUMID ZONE OF NIGERIA, Kaduna, Nigeria, 1984. Kaduna, Nigeria: ILCA, 1984.

MUTSAERS, H.J.W.; WEBER, G.K.; WALKER, P.; FISCHER, N.M. A field guide for on-farm experimentation. Croydon: IITA; CTA; ISNAR, 1997. 227p.

OSIRU, D.S.O.; WILLEY, R.W. Studies on mixtures of maize and beans with particular emphasis on the time of planting beans. In: SYMPOSIUM ON INTERCROPPING IN THE SEMI-ARID TROPICS (ICRISAT), Morogoro, Tanzania, 1976. Proceedings. Morogoro: ICRISAT, 1976.

PAL, U.R. Effect of Source and rate of nitrogen and phosphorus on yield, nutrient uptake and apparent fertilizer nutrient recovery by maize in the southern guinea savanna. Journal of Agricultural Science\& Technology, v.1, p.21-24, 1991.

SHELTON, H.M.; HUMPHREYS, L.R. Undersowing rice (Oryza sativa) with Stylosanthes guianensis. II. Delayed sowing time and crop variety. Experimental Agriculture, v.11, p.97-101, 1975a.

SHELTON, H.M.; HUMPHREYS, L.R. Undersowing rice (Oryza sativa) with stylosanthes guianensis. III. Nitrogen supply. Experimental Agriculture, v.11, p.103-111, 1975b.
SIPASEUTH, I.P.; SIYAVONG, P.; SIHATHEP, V.; CHANPHENGSAY, T.M.; SCHILLER, J.M.; LINQUI, B.; FUKAI, S. Agronomic constraints for improving yields of rainfed lowland rice in Laos. In: FUKAI, S.; BASNAYAKE, J. (Ed.). Increased lowland rice production in the Mekong Region. Laos: AGIAR, 2001. p.31-40. (Proceedings, 101).

SULLIVAN, P. Intercropping principles and production practices. Fayetteville: ATTRA, University of Arkansas, 2001. $16 p$.

WEBSTER, C.C.; WILSON, P.N. Agriculture in the tropics. 2.ed. London: Longman, 1980.

WILLEY, R.W. Intercropping - its importance and research needs. Part I Competition and yield advantages. Field Crops Abstracts, v.32, p.1-10, 1979a.

WILLEY, R.W. Intercropping - its important and research needs. Part 2. Agronomy and research approaches. Field Crops Abstracts, v.32, p.1-10, 1979b.

WILLEY, R.W.; OSIRU, D.S.O. Studies on mixture of maize and beans (Phaseolus vulgaris) with particular reference to plant population. Journal of Agricultural Science, v.77, p.531540, 1972.

WILLEY, R.W.; RAO, M.R. A competitive ratio for quantifying competition between intercrops. Experimental Agriculture, v.16, p.117-125, 1980.

Received April 08, 2005

Accepted April 04, 2007 